maize plants grown under conditions of potash deficiency do accumulate iron compounds in the node tissue and that the tissue develops a dark purplishbrown coloration and breaks down. He actually developed from this observation a method of diagnosing potassium deficiency in the soil, based upon the application of an acid solution of potassium thiocyanate to the nodule tissues of corn stalks when cut open lengthwise.

It would have been interesting to know whether Miss Robison found any significant differences in the potassium content and in the potassium-iron ratios between normal tubers and those that went black after boiling.

Sauncey Crook,

G. A. Cowie.

Sauncey Avenue,

Harpenden.

Aug. 15.

${ }^{1}$ NATURE, 147, 777 (1941).

2 Purdue Univ. Agric. Exp. Sta., Bull. 298 (1930).

\section{Vitamin C Content of Fresh, Canned and Dried Guavas}

The common guava, Psidium guajava, has not as yet received the recognition which it deserves as a potent source of ascorbic acid. Both in Hawaii ${ }^{1}$ and. in India ${ }^{2}$, values as high as $300 \mathrm{mgm}$. per $100 \mathrm{gm}$. have been reported for the fresh fruit, although many lower values are to be found in the literature.

We have investigated the vitamin $\mathrm{C}$ content of guavas from various parts of the Transvaal and the Cape Province. Ascorbic acid has been estimated by titration with indophenol in aqueous or dioxane solution, after extraction of the material with a 2 per cent solution of metaphosphoric acid. Canned guava juice has been assayed biologically by Key and Elphick's modification of the Hojer tooth method, the results being in agreement with those found by the chemical method.

$\begin{array}{lc}\begin{array}{c}\text { Condition } \\ \text { of fruit }\end{array} & \text { Ascorbic acid content } \\ \text { in mgm. per 100 gm. } \\ \text { Green and hard } & 250-350 \\ \text { Ripe and firm } & 300-450 \\ \text { Over-ripe and soft } & 50-100\end{array}$

In the above table is summarized the variation of vitamin $\mathrm{C}$ content of the fruit as a whole with its condition. It will be seen that the amount of ascorbic acid present in the fruit increases as it ripens but soon diminishes as the guava becomes soft. Firm fruit of high vitamin content may be stored at room temperature for several weeks without serious loss of vitamin but where the guava is ripe or infected with fruit fly the value decreases rapidly.

There does not appear to exist a wide variation in the vitamin content of fruit of different varieties or from various districts. On the whole, however, whitefleshed guavas are usually slightly richer in ascorbic acid than those with pink flesh.

of the different parts of the fruit, the skin has the highest content, the inner pulp contains little, and the stones none at all. The proportion of ascorbic acid found in skin, outer pulp and inner pulp may be as high as $12: 5: 1$.

When selected firm fruit is canned the ascorbic acid present in fruit and juice reaches levels of 200 $300 \mathrm{mgm}$. per $100 \mathrm{gm}$. The use of soft fruit is attended by a sharp decrease in the vitamin content, values as low as $18 \mathrm{mgm}$. per $100 \mathrm{gm}$. being found in some cases. These low values also obtain under

conditions favourable to the oxidation of the vitamin such as pulping or overcooking.

The most successful procedure for the preservation of the vitamin has been found by us to be drying at low temperature. The unpeeled fruit is quartered, the central pulp and stones removed and the residue blanched for two minutes. Thereafter the fruit is dried at $130^{\circ} \mathrm{F}$. for 10-12 hours and powdered. Powdered guava prepared in this manner contains 2,500-3,000 mgm. per $100 \mathrm{gm}$. (white) and 2,000 $2,500 \mathrm{mgm}$. per $100 \mathrm{gm}$. (pink). Failure to blanch the fruit prior to drying results in lower values $(1,000$ $1,500 \mathrm{mgm}$. per $100 \mathrm{gm}$.). Thus dried guavas compare favourably with other rich sources of the antiscorbutic vitamin such as dried rose hips, reported by Lund, Spur and Fridericia ${ }^{3}$ to contain $2,000 \mathrm{mgm}$. ascorbic acid per $100 \mathrm{gm}$. Moreover, the guava powder has a pleasant aromatic odour and practically no taste.

The above results, taken in conjunction with the wide distribution of the various species of guava and the ease with which they can be grown, justify their extensive cultivation and consumption. Full experimental details will be published later.

We wish to express our appreciation of the assis tance and co-operation accorded us by officers of the Food Inspectorate (Q Service-Supplies) and the Mobile Laboratory Unit of the South African Medical Corps.

\title{
LEON GOLBERG.
}

South African Institute for Medical Research, Johannesburg.

Leopold LeVy.

Government Chemical Laboratories, Johannesburg. July 12.

${ }^{1}$ Miller, C. D., Bazore, K., and Robbins, R. C., Hawail Agric. Fxp. Stat., Bull. 77 (1936).

'Ranganathan, S., Ind. J. Med. Res., 28, 239 (1935).

${ }^{3}$ Lund, H., Spur, B., and Eridericia, L. S., Biochem. J., 28, 1825 (1934).

\section{Intergranular Changes in an Iron Alloy}

THE phenomenon of intercrystalline attack by liquid metals on solid metallic crystalline aggregates is well known ${ }^{1}$, but the recorded cases which we have been able to find are chiefly of the attack of lowmelting metals such as tin, solder, lead and cadmium on high-tensile steel, and mercury on copper, nickel and aluminium alloys.

An example has now been met of attack by mercury on high-tensile steel. The steel is of the following analysis and mechanical properties.

\begin{tabular}{|c|c|c|}
\hline \multicolumn{3}{|c|}{ Analysis } \\
\hline C & $0 \cdot 28-0 \cdot 3$ & er cent \\
\hline $\mathrm{Ni}$ & $3 \cdot 75-4 \cdot 5$ & , \\
\hline $\mathrm{Cr}$ & $1 \cdot 0-1 \cdot 5$ & , \\
\hline Mo & Nil & \\
\hline $\mathrm{Mn}_{\mathrm{S}}$ & $\begin{array}{r}c .0 \\
\text { below } 0.0\end{array}$ & \\
\hline $\mathbf{P}$ & , & ", \\
\hline
\end{tabular}

Mechanical Properties

Ult. stress. c. 105 tons/sq, in.

El c. 14 per cent on $4 \sqrt{A}$

Red. of area 25 per cent min.

Izod value c. $25 \mathrm{ft} .1 \mathrm{~b}$.

The above mechanical properties are obtained by air-hardening. In a certain application an oilhardened nickel-chrome steel dowel pin $W$ in. diameter is pressed into a hole in this air-hardening steel with a slight interference fit $-0.0001-0.0002$ in. A series of failures in service was met. In every instance the fracture had two easily distinguishable zones-an initial zone exhibiting what appeared to be brittle fracture and a secondary zone of wellmarked fatigue type spreading from this. Microscopic: 